\title{
Character Association and Partitioning of Correlations of Yield and Its Attributing Traits in Late Sown Barley (Hordeum vulgare L.)
}

\author{
Banoth Vinesh*, L.C. Prasad and Ravindra Prasad \\ Department of Genetics and Plant Breeding, Institute of Agricultural Sciences \\ Banaras Hindu University, Varanasi - 221005, India \\ Corresponding author
}

A B S T R A C T

\begin{tabular}{|l|}
\hline Ke y w o r d s \\
$\begin{array}{l}\text { Correlation, Path } \\
\text { analysis, Barley, } \\
\text { association }\end{array}$ \\
\hline Article Info \\
\hline $\begin{array}{l}\text { Accepted: } \\
\text { 15 June } 2018 \\
\text { Available Online: } \\
\text { 10 July 2018 }\end{array}$ \\
\hline
\end{tabular}

Keywords

Correlation, Path analysis, Barley, association

\section{Introduction}

Barley (Hordeum vulgare L.) is an ancient cereal grain, which upon domestication has evolved from largely a food grain to a feed and malting grain $(2,16)$. It is fourth largest cereal crop after maize, wheat and rice in the world with a share of 7 per cent of the global cereal production. In recent times, about twothirds of the barley crop has been used for feed, one-third for malting and about 2 per cent for food directly. It is a major source of food for large population of cool and semiarid areas of the world, where wheat and other cereals are less adapted. Barley is an annual cereal grain crop that is consumed as a major feed for the animals. Other than playing its part as a major food crop, it is also used in beverages and beers. It is available in a variety of forms like whole barley, hulled barley, pearled barley as well as barley flakes. Barley contains about $75 \%$ carbohydrate, $9 \%$ protein and $2 \%$ fat. In energy terms, each gram provides about 3.3 calories. Barley grain is rich in zinc (up to $50 \mathrm{ppm}$ ), iron (up to 60 ppm) and soluble fibers, and has a higher content of Vitamins A and E than other major cereals.

Overall India's barley production was estimated to be 17.81 lakh MT spread over an area of 6.93 lakh ha for the year 2016-17 (1). 
Barley is an important winter cereal crop grown in the northern plains of India comprising the states of Uttar Pradesh, Bihar, Haryana, Rajasthan, Punjab, Madhya Pradesh, Himachal Pradesh and Uttarakhand that makes about $80 \%$ of total acreage of India.

It is grown as a rainfed crop in poor marginal soils due to its low input demand and lower cost of cultivation. It occupies $0.46 \%$ of the total cropped area, $0.62 \%$ of the food grains and $0.76 \%$ of the cereals in the country. Similarly it contributes $0.86 \%$ of the total production of cereals and $0.81 \%$ of the food grains in India. The most economically desirable use of barley is for the production of malt, the standards for which are quite stringent. Barley that does not meet malt quality standards often is utilized as feed for livestock, although some barley is produced solely as feed for animals, either as a grain or hay forage.

Barley is also used in alternative settings such as for ethanol production for bio-fuels and for reducing algae in ponds and waterway. Even though being an important crop, barley has been neglected in our country due to priority on wheat, rice and other cash crops. As a result the harvested area, production and productivity are falling down year by year.

A considerable number of grain production studies on barley include statistical correlations between agronomic and morphological characteristics and grain yield. Although these correlations are helpful in determining the principal components influencing final grain yield, they provide an incomplete representation of the relative importance of direct and indirect influences on the individual factors involved. It is known that the grain yield in cereals is determined by certain interrelated yield components. To identify the dimension of the effect of each yield component on grain yield is of importance for use in defining selection criteria for improving new varieties. Path coefficient and correlation analyses are used widely in many crop species by plant breeders to define the nature of complex interrelationships among yield. Correlation coefficients measure the absolute value of the correlation between variables in a given body of data. A path coefficient measures the direct influence of one variable upon another and permits the separation of correlation coefficient into components of direct and indirect effects. Path coefficient analysis specifies the cause and measures the relative importance of the characters. This information helps in formulating efficient scheme of multiple trait selection, as it provides a means of direct and indirect selection of component characters. Therefore, the objective of this study was to estimate the extent of association between pairs of characters in genotypic and phenotypic levels and thereby compare the direct and indirect effects of the characters.

Yield is a complex character; its direct improvement is difficult. Knowledge of correlation studies help plant breeder to ascertain the real components of yield and provide an effective basis for selection. The characters contributing significantly to yield can be identified and could be used as an alternate selection criterion in yield improvement programme. The genotypic correlation between characters provides a reliable measure of genotypic association between characters and helps to differentiate the vital associations useful in breeding from non-vital ones (8).

\section{Materials and Methods}

The present investigation was conducted at Genetics and Plant Breeding, Research Farm, Institute of Agricultural Sciences, Banaras Hindu University, Varanasi (U.P.) during rabi, 2016-17. Geographically, Banaras Hindu 
University is situated between $25^{\circ} 18^{\prime} \mathrm{N}$ latitude, $83^{\circ} 03^{\prime} \mathrm{E}$ longitudes and at an altitude of 128.93 meters above the mean sea level in the North Gangetic plain of eastern part of Uttar Pradesh. The experimental materials comprised of 101 exotic and indigenous genotypes which were maintained by BHU under All India Co-ordinated Wheat and Barley Improvement Project. These were laid in Randomized Block Design with three replications for the investigation. The sowing date was delayed by 20 days than the recommended date of sowing for the region to effect the terminal heat stress. Each treatment (genotype) was sown in line having $2.75 \mathrm{~m}$ length. The row to row and plant to plant distance of $25 \mathrm{~cm}$ and $10 \mathrm{~cm}$, respectively was followed. All the recommended agronomic practices for respective experimental conditions were followed to raise a good normal crops. Five competitive plants, in each plot were randomly selected and tagged well in advance for recording the observations. Data were recorded on the following characters viz., days to 50 per cent flowering, days to maturity, number of effective tillers/plant, number of grains/ear, spike length with awns (cm), spike length without awns (cm), stomatal conductivity (mmol $\mathrm{m}^{-2} \mathrm{~s}^{-1}$ ), SPAD values, leaf rolling, proline concentration ( $\left.\mu \mathrm{mol} \mathrm{g}^{-1}\right)$, 1000-grain weight (gm) and grain yield/plant (gm). Correlation coefficient was computed using formula given by (10) and direct and indirect effects of yield contributing factors were estimated through path analysis technique (21); (6).

\section{Results and Discussion}

\section{Correlation studies}

Yield is a complex character; its direct improvement is difficult. Knowledge of correlation studies help plant breeder to ascertain the real components of yield and provide an effective basis for selection. The characters contributing significantly to yield can be identified and could be used as an alternate selection criterion in yield improvement programme. The genotypic correlation between characters provides a reliable measure of genotypic association between characters and helps to differentiate the vital associations useful in breeding from non-vital ones (8).

In the present investigation, leaf rolling had evidenced a positive association with days to $50 \%$ flowering and SPAD while stomatal conductivity had negative effect on leaf rolling (Table 1). Similar reports were expressed by (15) and (4).

Days to $50 \%$ flowering exhibited significant positive affiliation with days to maturity, flag leaf length, spike length without awns but had negative association with 1000-grain weight, grains per ear, stomatal conductivity and effective tillers per plant. These findings were reinforced by the earlier reports of (7) and (12).

Plant height had positive and significant association with effective tillers per plant, stomatal conductivity. Spike length with and without awns. This was in accordance with the findings of (11) for plant height, number of effective per plant, number of grains per ear and 1000 grain weight.

1000-grain weight was positively associated with effective tillers per plant, stomatal conductivity, plant height while it was negatively associated with proline conductivity. Reports of (18) were in agreement with present findings.

Grain yield per plant had shown highly significant and positive correlation with effective tillers, stomatal conductivity, plant height grains per ear and 1000 grain weight which indicated strong association of these traits with the yield. 
Table.1 Correlation matrix of 14 quantitative traits in a diverse collection of 101 barley genotypes

\begin{tabular}{|c|c|c|c|c|c|c|c|c|c|c|c|c|c|c|}
\hline $\begin{array}{l}\text { Characte } \\
\text { r }\end{array}$ & DF & DM & FL & ET & SPAD & SC & PC & SL & SL W/O & PH & LR & $\mathbf{G} / \mathbf{E}$ & GW & GY \\
\hline DF & $\begin{array}{c}1.000 \\
0\end{array}$ & $\begin{array}{c}0.6974 * * \\
*\end{array}$ & $\begin{array}{c}0.2383 * * \\
*\end{array}$ & $\begin{array}{c}- \\
0.179 * \\
*\end{array}$ & $\begin{array}{c}0.2839 * * \\
*\end{array}$ & $\begin{array}{c}- \\
0.2037 * * \\
*\end{array}$ & 0.0912 & $\begin{array}{c}0.1194 \\
*\end{array}$ & $\begin{array}{c}0.3026^{* *} \\
*\end{array}$ & -0.0243 & $0.1255^{*}$ & $0.212^{*} * *$ & $0.239^{-} * * *$ & $0.1629 * *$ \\
\hline DM & & 1.0000 & 0.0848 & 0.0410 & $\begin{array}{c}0.2201 * * \\
*\end{array}$ & 0.0729 & 0.0130 & $\begin{array}{c}0.1437 \\
*\end{array}$ & $\begin{array}{c}0.3073 * * \\
*\end{array}$ & $\begin{array}{c}0.2703 * * \\
*\end{array}$ & -0.0107 & 0.0693 & -0.0929 & 0.0907 \\
\hline FL & & & 1.0000 & 0.0547 & 0.1103 & 0.0799 & $\begin{array}{c}0.1946 * * \\
*\end{array}$ & $\begin{array}{c}- \\
0.0006\end{array}$ & -0.0261 & 0.0577 & 0.0334 & $0.1595 * *$ & 0.0042 & $0.1423 *$ \\
\hline ET & & & & 1.0000 & -0.0252 & $\begin{array}{c}0.2843 * * \\
*\end{array}$ & -0.0884 & 0.0655 & 0.0305 & $\begin{array}{c}0.3328 * * \\
*\end{array}$ & -0.0529 & $\begin{array}{c}0.3060 * * \\
*\end{array}$ & $\begin{array}{c}0.2882 * * \\
*\end{array}$ & $\begin{array}{c}0.4171 * * \\
*\end{array}$ \\
\hline SPAD & & & & & 1.0000 & -0.0604 & $0.1459 *$ & $\begin{array}{c}0.1191 \\
*\end{array}$ & 0.0621 & -0.1051 & $0.1353^{*}$ & -0.0657 & -0.0398 & -0.0613 \\
\hline SC & & & & & & 1.0000 & 0.0583 & $\begin{array}{c}- \\
0.0509\end{array}$ & -0.0159 & $\begin{array}{c}0.3315 * * \\
*\end{array}$ & $\begin{array}{c}- \\
0.1596 * \\
*\end{array}$ & $\begin{array}{c}0.6308 * * \\
*\end{array}$ & $\begin{array}{c}0.3461 * * \\
*\end{array}$ & $\begin{array}{c}0.8116^{* * *} \\
*\end{array}$ \\
\hline PC & & & & & & & 1.0000 & $\begin{array}{c}- \\
0.0050\end{array}$ & -0.0647 & $-0.1301 *$ & 0.0723 & 0.0532 & $0.1627 * *$ & 0.0049 \\
\hline SL & & & & & & & & 1.0000 & $\begin{array}{c}0.3489 * * \\
*\end{array}$ & $0.1532 * *$ & 0.0788 & -0.0494 & -0.0007 & -0.0496 \\
\hline SLW/O & & & & & & & & & 1.0000 & $\begin{array}{c}0.2837 * * \\
*\end{array}$ & 0.0356 & -0.0514 & 0.0586 & 0.0235 \\
\hline $\mathrm{PH}$ & & & & & & & & & & 1.0000 & -0.0626 & $\begin{array}{c}0.3686 * * \\
*\end{array}$ & $\begin{array}{c}0.3234 * * \\
*\end{array}$ & $\begin{array}{c}0.4088 \text { ** } \\
*\end{array}$ \\
\hline LR & & & & & & & & & & & 1.0000 & $\begin{array}{c}- \\
0.1678 * *\end{array}$ & -0.0346 & $\begin{array}{c}- \\
0.1588^{* *}\end{array}$ \\
\hline $\mathrm{G} / \mathrm{E}$ & & & & & & & & & & & & 1.0000 & $\begin{array}{c}0.1926 * * \\
*\end{array}$ & $\begin{array}{c}0.7053 * * \\
*\end{array}$ \\
\hline GW & & & & & & & & & & & & & 1.0000 & $\begin{array}{c}0.3388^{* *} \\
*\end{array}$ \\
\hline GY & & & & & & & & & & & & & & 1.0000 \\
\hline
\end{tabular}

$\mathrm{DF}=$ Days to $50 \%$ flowering, FL=flag leaf length, ET=effective tillers/plant, SPAD, SC=stomatal conductivity, PC=proline concentration, $\mathrm{SL}=$ splike length with awn, SLW/O=spike length without awn, $\mathrm{PH}=$ plant height/E=grain per ear, $\mathrm{LR}=\mathrm{Leaf}$ rolling, $\mathrm{GW}=1000$ grain yielded= days to maturity, $\mathrm{GY}=$ grain yield 
Table.2 Direct (Bold) and Indirect effects of 13 quantitative traits on grain yield per plant in a diverse collection of 101 barley genotypes

\begin{tabular}{|c|c|c|c|c|c|c|c|c|c|c|c|c|c|}
\hline Character & DF & DM & FL & ET & SPAD & SC & PC & SL & SL W/O & $\mathbf{P H}$ & LR & G/E & GW \\
\hline DF & 0.0541 & 0.0378 & 0.0129 & -0.0097 & 0.0154 & -0.0110 & 0.0049 & 0.0065 & 0.0164 & -0.0013 & 0.0068 & -0.0115 & -0.0130 \\
\hline DM & -0.0131 & -0.0188 & -0.0016 & 0.0008 & -0.0041 & -0.0014 & -0.0002 & -0.0027 & -0.0058 & -0.0051 & 0.0002 & -0.0013 & 0.0017 \\
\hline FL & 0.0086 & 0.0031 & 0.0363 & 0.0020 & 0.0040 & 0.0029 & 0.0071 & 0.0000 & -0.0009 & 0.0021 & 0.0012 & 0.0058 & 0.0002 \\
\hline ET & -0.0264 & -0.0060 & 0.0081 & 0.1473 & -0.0037 & 0.0419 & -0.0130 & 0.0097 & 0.0045 & 0.0490 & -0.0078 & 0.0451 & 0.0425 \\
\hline SPAD & -0.0013 & -0.0010 & -0.0005 & 0.0001 & -0.0047 & 0.0003 & -0.0007 & -0.0006 & -0.0003 & 0.0005 & -0.0006 & 0.0003 & 0.0002 \\
\hline $\mathrm{SC}$ & -0.1166 & 0.0417 & 0.0457 & 0.1627 & -0.0346 & 0.5723 & 0.0334 & -0.0291 & -0.0091 & 0.1897 & -0.0914 & 0.3610 & 0.1980 \\
\hline PC & -0.0024 & -0.0003 & -0.0052 & 0.0024 & -0.0039 & -0.0016 & -0.0267 & 0.0001 & 0.0017 & 0.0035 & -0.0019 & -0.0014 & 0.0043 \\
\hline SL & -0.0044 & -0.0053 & 0.0000 & -0.0024 & -0.0044 & 0.0019 & 0.0002 & -0.0365 & -0.0127 & -0.0056 & -0.0029 & 0.0018 & 0.0000 \\
\hline S L W/o & 0.0082 & 0.0084 & -0.0007 & 0.0008 & 0.0017 & -0.0004 & -0.0018 & 0.0095 & 0.0272 & 0.0077 & 0.0010 & -0.0014 & 0.0016 \\
\hline PH & -0.0013 & 0.0148 & 0.0032 & 0.0182 & -0.0057 & 0.0181 & -0.0071 & 0.0084 & 0.0155 & 0.0547 & -0.0034 & 0.0201 & 0.0177 \\
\hline LR & -0.0015 & 0.0001 & -0.0004 & 0.0006 & -0.0016 & 0.0019 & -0.0009 & -0.0010 & -0.0004 & 0.0008 & -0.0121 & 0.0020 & 0.0004 \\
\hline $\mathrm{G} / \mathrm{E}$ & -0.0592 & 0.0193 & 0.0444 & 0.0853 & -0.0183 & 0.1758 & 0.0148 & -0.0138 & -0.0143 & 0.1027 & -0.0468 & 0.2787 & 0.0537 \\
\hline GW & -0.0075 & -0.0029 & 0.0001 & 0.0091 & -0.0013 & 0.0109 & -0.0051 & 0.0000 & 0.0018 & 0.0102 & -0.0011 & 0.0061 & 0.0315 \\
\hline GY & - & 0.0907 & $0.1423 * * *$ & 0.4171 & -0.0613 & $0.8116 * * *$ & 0.0049 & -0.0496 & 0.0235 & $0.4088 * * *$ & ${ }^{-}$ & 0.7053 & $0.3388 * * *$ \\
\hline
\end{tabular}

${ }^{*}$ Significant at $\mathrm{p}<0.05 ;{ }^{* *}$ Significant at $\mathrm{p}<0.01 ;{ }^{* * *}$ Significant at $\mathrm{p}<0.001$

$\mathrm{R}^{2}=0.754$, Residual effect $=0.49$ 
These findings were in accordance with the results reported by (9) and (20). While it exhibited negative and significant correlation with days to $50 \%$ flowering and leaf rolling similar result was reported by (3). Therefore, grain per ear, effective tillers per plant, plant height, spike length with awn and 1000 grain weight can be identified as major characters contributing towards yield directly and indirectly and selection based on these characters are effective in developing high yielding barley genotypes/varieties.

\section{Path coefficient analysis}

The correlation coefficient indicates the degree of relationship between characters but it alone does not give clear picture of measure of association between yield and its components. It is most important to know the direct and indirect influences of yield components for selecting suitable genotypes for improving the yield. Selection for yield is more effective when it is based on component characters which are highly heritable and positively correlated with yield. When more number of variables are considered in correlation the association becomes more complex and less obvious. The path analysis is useful under such circumstances. This gives a clear picture of the direct and indirect effects of various traits on yield. Therefore, present investigation, path analysis was carried out to generate such information of direct and indirect effects on yield by its

Grain per ear revealed positive direct effect on the grain yield per plant while most the correlation between these two traits was contributed by indirect effects via stomatal conductivity (Table 2). This was in accordance with the findings of (5); (14); (13).

Even though 1000-grain weight had positive association with grain yield per plant most of this correlation was contributed by indirect effect via stomatal conductivity this report was reinforced by the earlier findings of (17). Stomatal conductivity had significant positive effect on grain yield per plant while it contributed to most the negative correlation of days to $50 \%$ flowering on grain yield per plant through indirect effects. This was in accordance with the findings of (5); (14). Effective tillers per plant had significant positive effects on yield per plant while it has considerable indirect effects via stomatal conductivity which were similar to the earlier findings of (20); (19). The residual $(\mathrm{R})$ effect was 0.49 , therefore remaining $50 \%$ of the yield was contributed by traits which were not considered in this experiment.

\section{References}

1. Anonymous (2017). Progress Report of All India Coordinated Research Project on Wheat \& Barley 2016-17, Vol. VI. Barley Network. ICAR-Indian Institute of Wheat and Barley Research, Karnal, India. P. 280.

2. Baik BK and SE Ullrich. (2008). Barley for food: Characteristics, improvement, and renewed interest. Journal of Cereal Science 48: 233-42.

3. Bhutta, W.M., Tahira., Muhammad, I. (2005). Path-coefficient analysis of some quantitative characters in husked barley. Cadero de pesquisaSerieBiologia, 17(1): 65-70.

4. Carpc, E.B., Celk, N. (2012). Correlation and path coefficient analysis of grain yield and yield components in two- rowed of barley (Hordeum vulgareconvar. distichon) varieties. Notulae Scientia Biologicae,4 (2): 128-131.

5. Desheva, G. (2016). Correlation and pathcoefficient analysis of quantitative characters in winter bread wheat varieties.Trakia Journal of Sciences, 14 (1): 24-29.

6. Dewey, D. R., Lu, K. H. (1959). Correlation and path coefficient analysis components of crested wheat grass seed production. Journal of Agronomy and Crop Scienc, 51: 515-518.

7. Drikvand, R., Samey, K., Hossinpor, T. (2011). Path Coefficient Analysis in Hullless Barley under Rainfed Condition. 
Australian Journal of Basic and Applied Sciences, 5 (12): 277-279.

8. Falconer, D. S. 1981. Introduction to quantitative genetics. $2^{\text {nd }}$ Edition. Oliver and Boyd, Edinburg, London.

9. Hailu A, Alamerew S, Nigussie $M$, Assefa E (2016) Correlation and Path Coefficient Analysis of Yield and Yield Associated Traits in Barley (Hordeum vulgare L.) Germplasm. Adv Crop Sci Tech 4: 216.

10. Johnson, H.W., Robinson, H.E. and Comstock, R.F. (1955). Genotypic and phenotypic correlations insoyabeans and their implications in selection. Agron. J. 47: 447-483.

11. Kishore, R.L., Pandy, D.D., Varma, S.K. (2000).Genetic variability and character association in hull-less barley(Horeum vulgare L.). Crop Research (Hissar), 19 (2): 241-244.

12. Kumar, M., Shekhawat, S. S. (2013). Correlation and path coefficient studies in barley (Hordeum vulgare L.) under dual purpose condition. Electronic Journal of Plant Breeding, 4 (4):1313-1318.

13. Mittal, V.P., Brar, K.S., Singh. P. (2009). Interrelationships and path coefficient analysis for yield and component characters in barley [Hordeum vulgare (L.)]. International journal of Agricultural Sciences, 5 (1): 151-153.

14. Mohammad, Z., Marefat, G., Jafar, Z., Majid, K., and Babak. A. (2011). Correlation Analysis and Path Analysis for Yield and its Components in Hulless Barley. Advances in Environmental
Biology, 5 (1): 123-126.

15. Mohsin, T., Khan, N. and Farzana.N. (2009). Heritability, phenotypic correlation and path coefficient studies for some agronomic characters in synthetic elite lines of wheat. Journal of Food, Agriculture \& Environment,7 (3\&4): 278 $-282$.

16. Pourkheirandish $\mathrm{M}$ and $\mathrm{T}$ Komatsuda. (2007). The importance of barley genetics and demonstration in a global perspectives. Annals of Botany 100: 9991008.

17. Singh, J., Prasad, L. C., Madakemohekar A. H., and Bornare S. S. (2014). Genetic variability and character association in diverse genotypes of barley (Hordeum vulgare L.). The bioscan,9 (2): 759-761.

18. Singh, S. R. J., Yadav, H.S., Singh, S.M. (2003). Assessment of yield contributing characters in rainfed barley. Advance in Plant Sciences, 16 (1): 325-327.

19. Srivastava, S., Anil, S., Sanjiv, K., Anil. K. (2012). Correltion and path coefficient studies for yield and yield contributing traits in malt barley (Hodeum vulgare L.). International Journal of Engineering \& Science Research, 2 (3/2):100-110.

20. Tofiq, S. E., Taban, N., Hama Amin.,Suaad, M. S. A., Dana, A. A.(2015). Correlation and path oefficient analysis of grain yield and yieldcomponents in some barley genotypes created by full diallel analysis in sulaimani region for $\mathrm{f} 2$ generation. International Journal of Plant, Animal and Environmental Sciences, 5 (4): 76-79.

\section{How to cite this article:}

Banoth Vinesh, L.C. Prasad and Ravindra Prasad. 2018. Character Association and Partitioning of Correlations of Yield and Its Attributing Traits in Late Sown Barley (Hordeum vulgare L.). Int.J.Curr.Microbiol.App.Sci. 7(07): 2020-2026. doi: https://doi.org/10.20546/ijcmas.2018.707.238 